2018 TheoLogica

An International Journal for Philosophy of Religion and Philosophical Theology

S.I. NEW THEMES IN ANALYTIC DOGMATIC THEOLOGY

DOI: https://doi.org/10.14428/thl.v0i0.1323

\title{
Temple Theology, Holistic Eschatology, and the Imago Dei: An Analytic Prolegomenon
}

\author{
JAMES T. TURNER, JR. \\ Fuller Theological Seminary \\ jtturner@fuller.edu
}

\begin{abstract}
In this paper, I offer something of a prolegomenon, outlining some areas in which certain strands of biblical theology and analytic theological reflection can be mutually informative. To do so, my paper unfolds in three ways. In the first section, I provide some reasons to think that biblical theologians are onto a reading of Scripture that merits the attention of analytic theologians. In section II, I outline some areas in the biblical theological data that would benefit from analytic exploration and reflection. Finally, in sections III and IV, I present a test case: the imago Dei and the importance of the future bodily resurrection. This should help show how this strand of biblical theology and analytic theological reflection can be mutually informative.
\end{abstract}

Keywords: Holistic Eschatology, Analytic Theology, Temple, Imago Dei, Bodily Resurrection

In biblical theology, there's a body of literature growing in prominence that expresses two related (purportedly biblical) themes: what's been called "holistic eschatology" and what's been called "temple theology." ${ }^{11}$ A gloss on these themes paints a picture of the point and purpose-the telos-of creation and the things in creation, namely that the whole creation is meant to be a temple for YHWH. The way this literature presents the case, the Christian Scriptures (to include the Hebrew Bible/Old Testament) declare, from the creation narrative in Genesis 1 to the revealing of the New Creation in Revelation 22, the future redemption of the entire material universe, not just human creatures (Bauckham 2007, 311; Beale 2004; Beale and Mitchell 2014; Middleton 2014, 159, 163 and throughout). And this is purportedly because the cosmos has been, from the beginning, purposed to be a home for the triune God. ${ }^{2}$

\footnotetext{
1 "Holistic eschatology" appears to be a term coined by Richard Bauckham in (Bauckham 2007). "Temple Theology" as a way to think about the Christian story appears to be a term coined by N. T. Wright in, at least, (Wright 2017). But, as you'll see through the citations and information present in section I of the paper, other biblical theologians are presenting biblical theological matters along the same lines, even if not with the labels Bauckham and Wright provide.

${ }^{2}$ John Walton explicates the difference between a house and a home vis-à-vis God's work in setting up
} 
Whether one agrees with this assessment of one of the metanarratives of the Christian Scriptures, or whether one thinks that there's a metanarrative in the Scriptures at all, the surge in the biblical theology literature advancing these lines, in my view, demands some attention. One part of the theological guild that may well need to consider the deliverances of the scholarship detailing holistic eschatology and the inter-related temple theology is analytic theology. I wish to begin doing so in this paper.

What I want to offer here, though, isn't an argument for this particular reading of the biblical narrative (though I will offer some cursory reasons to think it's plausible). Instead, I aim to offer something of a prolegomenon, outlining some areas in which these strands of biblical theology and analytic theological reflection can be mutually informative. To do so, my paper unfolds in three ways. In the first section, I provide some reasons to think that the biblical theologians are onto a reading of Scripture that merits the attention of systematic theologians, and analytic ones, in particular. In section II, I outline some areas in the biblical theological data that would benefit from analytic exploration and reflection. Finally, in sections III and IV, I present a test case: the imago Dei and the importance of the future bodily resurrection. This should help show how this strand of biblical theology and analytic theological reflection can be mutually informative.

\section{Taking Seriously Biblical Theology}

In a paper given at the 2017 Logos Conference in St. Andrews, UK, N. T. Wright opines:

"If systematic or analytic theology has no room for these themes of Temple and image, of Israel as the Temple-guardians and Jesus as the Temple in person, of the Paschal victory through which the new Temple is to be established, not just as decoration around the edges of something else but as central load-bearing themes, then such theology has a hollowness at its heart" (Wright 2017, 7. His emphasis).

I take this to be an exhortation to systematic/analytic theologians to do what Wright calls "temple theology" (Wright 2017, 3). ${ }^{3}$ That is, to take seriously-as "central and

creation, moving it from a house (with material parts) to a home (wherein those parts are functioning in the desired way). Compare: one's just moved into a new house with unpacked boxes and unarranged furniture; it is yet to be a home. See John H. Walton's compelling case concerning this notion as it relates to the creation story in Genesis 1 and 2 in (Walton 2009; Walton 2015, 47 in particular).

${ }^{3}$ This is not to be confused with the "Temple Theology" project of Margaret Barker, which, so far as I can tell, isn't orthodox (it posits, for example, that the Bible teaches that YHWH and "God Most High" are different beings, that Torah replaced Wisdom, a female deity whom Barker supposes is the deity Asherah (whom she says the Israelites were supposed to worship), among other things. See, for example (Barker 2012). 
load-bearing" - the idea that the cosmos itself is meant to be a temple for YHWH, a place that is home for him.

As I stated earlier, there is a growing list of reasons to take seriously this line of reasoning. To begin, it's becoming increasingly clear (so far as I understand the biblical theologians) that the creation narrative in Genesis 1 is written in such a way as to communicate that what God is doing in the narrative is building a temple. One of the ways readers of this story are supposed to know this is through reflecting on the last thing that is put into the temple, as was the case (so say the exegetes) in Ancient Near Eastern practice, viz., the image of the deity (Middleton 2005, 87). True to form, this happens on Day 6, the last day of YHWH's "work" of creation (Gen. 1:26-31).

Another way the writer alerts his reader to the temple-building theme in Genesis 1 and 2, perhaps the most important picture of all for the Hebrews, is the divine rest on the seventh day (Levenson 1984, 288; Weinfeld 2014, 149 - 159). This is because, in Ancient Near Eastern thought, temples are places in which gods rest. It is important to note here that, according to the ANE specialists, 'rest' doesn't mean sleeping, relaxing, or the like. It means, instead, ruling in an unfettered sort of way, a way in which one is not beset on any side by one's enemies or forces of chaos. The same is true, so say biblical theologians, of the resting that YHWH does on Day 7 (Gen. 2:1-2). God takes up residence and rests-that is, rules -in his temple (Walton 2015, 47; Beale 2004, 66; Middleton 2005, 81; Weinfeld 2014).

Though there are myriad ways in which the writer of Genesis purportedly alerts his reader to the temple building narrative of Genesis 1, one final way worth mentioning is the seven-day structure given in Genesis 1 and the beginning of Genesis 2. It's worth mentioning because of the way that the temple-building story is told in 1 Kings 6-8, the construction of Solomon's Temple. The proliferation of sevens deployed in the 1 Kings temple-building narrative is, by some, taken to be emblematic of temple building (Levenson 1984, 288; Middleton 2005, 83; Beale 2004, 61). Moreover, some think that the Genesis narrative's use of the seven-day structure indicates that the writing of the creation account is post-exilic, that is to say, well after the building and destruction of Solomon's Temple, as a way to encourage those Israelites returning from exile to build the Second Temple. ${ }^{4}$ I don't have the requisite expertise to make a judgment about whether that's a correct understanding of the timing of the writing of the early chapters of Genesis. But, it seems to me that the issue of timing isn't overly important to the larger point. For, it could be that, had Genesis 1 and 2 been a part of the original five books of Moses, the writer(s) of 1 Kings might well have been using it as a typological

\footnotetext{
${ }^{4}$ By Middleton's lights, the dating is ambiguous for a number of reasons. See (Middleton 2005, 144ff). For an argument that the Pentateuch (of which Genesis 1 is a part) is postexilic, see (Enns 2012, 5ff).
} 
pattern for his account of the creation of the Solomonic Temple. ${ }^{5}$ Whatever the direction of influence, it does seem that the creation account and the building of Solomon's Temple are meant to mirror each other for at least one reason: to express that the cosmos is meant to be YHWH's temple.

Similarly, these scholars have been at pains to demonstrate that Solomon's Temple and, indeed, the Tabernacle, were meant to be microcosms, pictures of the creation in miniature (Levenson 2014, 238 - 247). From the outer court of the Tabernacle/Temple and its "sea," passing through the veil depicting the heavenly host and into the Holy of Holies - the very presence of $\mathrm{YHWH}$ - one is, so exegetes tell us, supposed to picture the visual representation of the point and purpose of the created order as a place within which God can be at home with his creation. ${ }^{6}$

Now, this Old Testament Temple theme is thought to run through the NT, as well. Purportedly, one can see this clearly in the opening chapter of John's gospel. Here, says Wright, John is writing a new Genesis echoing the very first line of the Genesis 1 (John 1:1a: En archē en ho logos/In the beginning was the Word) complete with Temple imagery: kai ho logos sarx egeneto kai eskēnōsen en hemmin (and the word became flesh and tabernacled with us (John 1:14a). And, thinks Wright, if John is writing a new Genesis 1, an account of new creation, John is also writing a new temple building story (Wright 2017, 3ff). Again, on this way of reading the Christian Scriptures, creation is a temple. So, a new creation is a new temple.

Biblical exegesis concerning eschatological matters is beginning to point in the same direction. G. K. Beale and J. Richard Middleton have shown rather persuasively that the imagery John the Revelator deploys in his description of the New Jerusalem in Rev. 21:16-21, particularly its cubic shape and jeweled adornment, means to draw the reader's mind to 1 Kings 6 and the cubic dimensions of the Holy of Holies in Solomon's Temple. The use of the cubic imagery in Revelation is key: as it turns out, the entire cosmos is now a Holy of Holies, a place full of the unfettered presence of God (Beale 2004, 23, 348; Middleton 2014, 170 - 171).

Thus far is a gloss on the way a number of biblical theologians are reading the Christian Scriptures. And, if there's merit to these claims, then there's a possibility that, if the Christian story is true, then YHWH's purpose for his creation is for it to be his temple, his home. And, if that's correct, then what's going on at the eschaton-at

\footnotetext{
${ }^{5}$ For a developed overview of paradise-Garden -imagery in the Solomonic Temple, see Stager (2014, 99 - 108).

${ }^{6}$ More imagery in the OT abounds, but space requires I leave the rest for homework. For a nearly exhaustive treatment, see (Beale 2004, 29 - 80). This sort of imagery is attested too in (Walton 2009, 81). Peter Enns also suggests that, "The temple that the Israelites constructed, at God's command, was an instantiation of God's true temple, the heavens and the earth. This is why Israel's sanctuaries are described as minicreations" (Enns 2012, 72). According to John Lundquist (2014) the notion that temples are microcosms is a common them in ANE religion (51 - 54).
} 
Christ's parousia - is that YHWH is setting all things right. Following the insights of John Walton, YHWH will finish setting his house in order and making it a home (Walton 2009; Walton 2015, 47; cf. also Weinfeld 2014). Christian eschatology, on this view, suggests that the "newness" of the New Creation isn't numerical newness; it's qualitative newness. That's the picture these scholars propose is given to readers in OT passages like Ezekiel 40 - 48, Isaiah 65:17-25; 66:1-24, and the NT in Romans 8:18-30, Revelation 21 and 22, et. al. With John Polkinghorne, reading Scripture this way suggests that the New Creation is not a further instance of creatio ex nihilo; this material creation isn't to be crumpled up and thrown away with a new one being made out of nothing. Rather, the New Creation results from an act of creatio ex vetere (out of the old) (Polkinghorne 2002, $50)$.

As I've argued elsewhere, there's at least one further reason to take the redemption of the present cosmos as YHWH's eschatological goal. The resurrection of Jesus provides a foreshadowing, a first instance (in the biblical wording: a first-fruits) of a wider-scale promised redemption (Mugg and Turner 2017, 122 - 124). ${ }^{7}$ Jesus's whole body is raised from the dead and walks out of the tomb. That it's the numerically same body that walks out - though qualitatively changed - is the explanation for why the tomb is empty (cf. Mugg and Turner 2017, 127). ${ }^{8}$ The resurrected Jesus qua human being is a microcosm of the eschatological condition of this very cosmos. This fits with the proffered narrative of Christian Scripture I outline above. Jesus is thus the center and source of the wider New Creation, the very God that makes the New Creation his Temple (cf. Rev. 21:22-23; 22:1-2a). From this, one should be able to sense the "whole" in "holistic eschatology." Eschatology is not just about the future end of human beings; it's about the future end (telos) of God's good creation. ${ }^{9}$

Now, the analytic reader will have noticed that some of the language, indeed, some of the "central and load-bearing" (to borrow Wright's phrasing) language, in the preceding discussion is more murky than clear. Following Mike Rea, I take it that a hallmark characteristic of good analytic theology is to prioritize precision, clarity, and logical coherence (Rea 2009, $5-6$ ). ${ }^{10}$ In the next section, then, I'll attempt to draw attention to some of the unclear points in the above discussion. This I hope will serve as a sort of prolegomenon inviting analytic theologians to attend to the biblical theological project described above. To reiterate: the reason I think analytics should be compelled to do this is because the swell in scholarly support for this reading of Christian Scripture demands attention, such that it might shift central doctrines in Christian theology. (Compare: the findings of the biological sciences, particularly evolutionary biology, and the ways in

\footnotetext{
7 See also (Bauckham 2007, 315; 2014, 26 - 27; Wright 2015, 179; and Rowland, 2008, 57 - 64).

8 See also (Fergusson 1985, 303; 2000, 3; and Harris 1983, 44) on this score.

9 See the excellent and clear way that Bauckham spells this out in $(2007,316)$.

10 See also (McCall 2015, 17 - 18).
} 
which theologians and philosophers have seen fit to re-think The Fall, death, suffering, and teleology in the creation.) I'll analyze and discuss a further area needing analytic examination in sections III and IV. For now, I turn my attention to highlighting some issues in the foregoing biblical theological narrative that would benefit from analytic reflection.

\section{Where Might the Analytic Theologian Help?}

What follows is not a comprehensive overview of the theological issues brought to light by the recent biblical theological work in temple theology and holistic eschatology. It's neither comprehensive of the way I've glossed the biblical theological literature, nor of the issues that crop up in the field generally. ${ }^{11}$ Instead, I wish to pull some highlights and offer some reasons for thinking that, if this sort of biblical theology is to make inroads into the wider theological academe, it will benefit from analytic attention. I've already intimated that it should receive some attention, now I'll try and show where, in particular.

God's omnipresence. The literature I outline above makes much of God's fashioning the material cosmos into his home. Indeed, these biblical theologians are wont to employ the prophetic language wherein YHWH's glory and the knowledge thereof "fills the earth as the waters cover the sea" (Hab. 2:14). ${ }^{12}$ This surely sounds right, and it sounds biblical (where 'biblical' means something like: implied by the Christian Scriptures understood to be read as a coherent whole). But it's not clear what it means. What kind of thing is YHWH/YHWH's glory such that he/it could fill anything? Yes, the Bible presents its readers all sorts of passages detailing how YHWH and/or YHWH's glory "fills" the Tabernacle/Temple (Ex. 40:34; 1 Kings 8:6-13; 2 Chron. 7:1) and that he/his

${ }^{11}$ To note one example, one that many analytic theologians might find interesting, is the thesis that the original task given to the human pair, Adam and Eve, was a task to subdue the wild area of the creation, outside of the Garden in Eden, that YHWH left for the work of his vice-regents, viz., humans. One of the prevailing implications of this line of thought is that, outside of the Garden, there was death, non-order, and so on. It was the job of the humans to co-rule with YHWH and expand the glorious presence of YHWH, and his wise order, throughout the cosmos, to make all of it his Temple. Does such a view of the creation account provide a theodicy, or does it just push back a step the question of why God would set up such a world in the first place? Does such a view mean that, in the beginning, humans could have, through co-ruling with the only wise God, been able to manipulate and direct elementary particles to overcome the deleterious effects of entropy? It should be obvious that these sorts of questions are ripe for analytic inquiry. For, if this way of thinking of the human being turns out to be nonsense, one might well be within her rights to reject such a reading of the biblical text. For more on this, Cf. (Fretheim 2014, 321ff; Wright 2004, 131; McDonough 2017, 185ff; Walton 2015, 56 - 57; and Osborn 2014).

12 For similar scriptural sentiments see: Ps. 57:5, 57:11, 72:19, 108:4-5; Hab. 2:14; Isa. 6:3, 11:9. For a representative sampling of biblical theologians deploying this language, see (McDonough 2017, 205; Wright 2015, 176; and Beale 2004, 163). 
glory can be "seen," even if only his back-side (Ex. 33:17-23). But, the Christian tradition has always seen fit to think about YHWH in non-physical, immaterial terms; that is to say, one is encouraged to think about YHWH in such a way that he cannot be seen (save for in the God-man, Jesus Christ). YHWH created the material cosmos; he is not, himself, material. And if the terms 'immaterial,' 'material,' and the like are understood in a way consistent with the way Descartes, for example, might have understood them, then it doesn't seem possible that $\mathrm{YHWH} / \mathrm{YHWH}^{\prime}$ ' glory could fill something, if he and/or it is not a material or physical object (in the Cartesian vernacular: if he or it is not a res extensa) (Descartes 1968, 6.78).

The pantheist or panentheist might, at this point, wish to offer her own views to explain how God and his glory can fill the earth. Classically, however, pantheism and panentheism prove troublesome for Christian theology. The majority report is that they blur the distinction between Creator and creation. ${ }^{13}$

There's work to be done, then. Providing an explanation for how YHWH can "fill" the earth is one area in which, by my lights, the biblical theologian might benefit from the analytic theologian's help, at least if she wants coherently to affirm the classical conception of the Christian God. For if one can't get clear on what one means when one suggests that the cosmos is meant to be God's home (particularly, YHWH's), or one cannot begin to provide a model for how such a thing might be possible, then it's not clear why anyone should listen to such a thesis. Note that this is not to say that one cannot get clear on what this sort of language means; nor is it to say that there is no model forthcoming. Indeed, I think one can get clear on this language; moreover, it's part of my intention in this paper to invite attempts at model building.

Alternatively, suppose the biblical theologian denies the classical way of thinking about YHWH. ${ }^{14}$ In other words, suppose that the biblical theologian thinks that the traditional notion of God as immaterial and "outside" of space and time (and so on) is faulty, that it does not report accurately the teaching of the biblical text. Here, too, the analytic theologian can provide resources for thinking through the most coherent models of the divine Being. Biblical theology, after all, is not designed to carve reality at the joints and build metaphysical models; such is the work of the metaphysician. The analytic theologian can take her skill in analytic metaphysics, her knowledge of the biblical and theological material, and partner with the biblical theologian to fill out the biblical theologian's concepts. As a multi-disciplinary field, analytic theology is meant to bring disparate disciplines into conversation. My contention, then, is that analytic theologians have a vital role to play in systematizing and clarifying this burgeoning work in biblical theology, not least with respect to God's omnipresence.

\footnotetext{
${ }^{13}$ For an overview of pantheism, panentheism, and its relation to classical theism, see (Mullins 2016).

${ }^{14}$ Thanks to an anonymous reviewer for this line of thought.
} 
Jesus is the Temple; The New Creation is the Temple. The gloss I give on the biblical theological story about the telos of creation paints a picture in which two statements are true. (I) That Jesus is the archetypical Temple toward which the OT Tabernacle/Temple were meant to point. And (II) that the redeemed creation, the New Creation, will be YHWH's temple; this is because the creation was always meant to be God's temple. But how is it possible that both are true? Is it possible? Again, analytic insights seem needed. For, it's one thing for a biblical theologian to paint a beautiful picture of the narrative of the biblical story; it's another thing to make it logically and metaphysically coherent. In my view, punting to the mysterious "somehow" is less than helpful, at least in the thoughtful and learned confines of academic discourse. To get a sense of what I mean by the "somehow" move, here is Wright deploying it:

\begin{abstract}
"Those whose ear can only hear one note at a time will find it strange to be told that all these notes - temple, image, divine glory, high priest, Messiah - can somehow come together...like the varied rainbow colours brought back into the pure white light from which they came, so Jesus turns out to be both the true Temple and the true Image with that Temple and the High Priest... and, of course, the victorious Messiah" (Wright 2017, 5. First emphasis his).
\end{abstract}

Notice that, in the explanation, what's offered is a metaphor: rainbow colors working back into white light. I get the image; I worry that the semantic content of the metaphor outstrips its propositional content (Rea 2009, 5 - 6). That is to say, I'm not sure that there's an explanation of the metaphor-one that makes it propositionally clearforthcoming. For, it's not clear how disparate and prima facie competing biblical themes might be the result of a refracting theological prism; nor is it clear why one should think they are. Even less clear is what a theological prism is or might be. And I grant that the themes about which Wright speaks are true! But much more needs to be said to show that they are, in fact, true and how they are true. This is particularly so given what a number of these exegetes say: the Christian tradition, up until now, has been largely missing the point with respect to the purpose of God's creation and human beings within it. ${ }^{15}$ Well, if one is going to offer a reading of the biblical narrative that goes against the larger tradition, systematicians are within their rights to require that biblical theologians provide some clear reasons to think that their tradition-competing explanation (if it is tradition-competing) is metaphysically and logically coherent.

Why think that systematic theologians are within their rights to ask for clear reasons here? The most obvious answer is that, if a given explanation, $E$, of some phenomenon, $P$, is metaphysically and logically incoherent, then $E$ is false. That's just the nature of explanations (insofar as explanations are given in the form of propositions). There's

\footnotetext{
${ }^{15}$ But see (McDonough 2017). He thinks that these themes have been, even if not as clearly explained, a driving force in the early church's theology of creation and new creation.
} 
another answer, though, that gets to a larger and more salient point. It is common-coin for theologians to suggest that the history and development of doctrine in the Christian tradition is, at bottom, overseen by the Holy Spirit. When one comes back at the tradition with a competing doctrine, however, one implicitly or explicitly suggests that the Holy Spirit's oversight has, at least in some particular respect, allowed for an error. Obviously, the Holy Spirit's oversight doesn't rule out of court a revisionary critique of Christian doctrine in light of new scriptural or theological insights. The various expansions, clarifications, and corrections of Christian doctrine in the ecumenical creeds, Trent, Vatican I, Vatican II, the Protestant Reformation, and the various and sundry Protestant synods, confessions (and so on) prove the point. Notwithstanding debates about whether the theologian ought to give pride of place to tradition or Scripture as the primary source of Christian theology, that deference of some kind is afforded to the tradition's reading of Scripture (insofar as that's locatable, which is an issue that takes us too far afield) vis-à-vis Christian doctrine seems prima facie reason to be cautious about doctrines that run (purportedly) against the deliverances of that reading (Crisp 2009, 8 19).

Having said this, I anticipate a worry from the systematician's side of the aisle: that I'm prizing reason over revelation. To alleviate this worry, notice that I am not suggesting that clear metaphysical explanations are necessary to take seriously a particular doctrine or reading of Scripture. Rather, what (in my view) is necessary is that proposed readings of the biblical text and corresponding doctrinal deliverances not be metaphysically impossible or incoherent. This is simply because metaphysically or logically impossible things are nonsense (and so, calling them "things" is a misnomer). Of course, Christian theology allows (perhaps, even demands) mystery. Consider the Incarnation. It's important, though, to recall that the tradition has been at pains to provide explanations of the God-man that are not metaphysically or logically incoherent. ${ }^{16}$ The same holds true of other doctrines that are beyond our complete comprehension (e.g., The Doctrine of the Trinity). ${ }^{17}$ So far as I can tell, no thinker providing a model of these doctrines suggests that his/her proposed model is a full explanation of what's going on; the models are, instead, offered as genuine possibilities (that is to say: not incoherent). What I'm calling attention to in the present paper, then, is a need for constructive theological work that does for temple theology and holistic eschatology what current analytic theology does for the doctrines just mentioned.

So far, I've provided reasons to think that the following two things are true: (a) that there are good exegetical reasons for affirming the recent biblical theology of temple

16 Timothy Pawl's recent work is one fine example: (Pawl 2016). Oliver Crisp advances christological models that take mystery seriously, too. He provides reasons to caution against thinkers who demand that a clear model of that which is beyond our ken. See (Crisp 2007, 36 note 2).

${ }^{17}$ See, e.g., William Hasker's recent treatment of the doctrine wherein he proposes a new model of the Trinity in (Hasker 2013). 
theology and holistic eschatology and (b) that these recent developments in biblical theology would benefit from analytic attention. Moreover, if what the biblical theologians say is true, namely, that these biblical theological themes are central to the Christian story, then it stands to reason that the doctrinal developments out of this story may well be every bit as important to Christian theology as the doctrines of the Trinity and Incarnation (for, ex hypothesi they tell us what the point and purpose is of God's creation, his mission in Jesus, and the consummation of all things). For purposes of this paper, I will proceed as though it's true that the biblical theological deliverances I've outlined provide Christianity doctrines that are central to the Christian faith. To do so, I offer a test case that uses the exegetical deliverances of the biblical theologian and the conceptual resources of analytic theology to show how the two disciplines can be, and should be, mutually informing.

\section{The Divine Image in YHWH's Temple}

According to the biblical theology outlined above, the cosmos is meant to be YHWH's temple. One of the ways the Christian is supposed to know this is because, in the very outset of the Christian Bible, the image of the deity is the last thing to be put into the creation. This, as you'll recall, is suggestive of Ancient Near Eastern temple-building practices wherein the last thing placed in a god's temple is his/her image. The writer of Genesis 1 paints the same picture of YHWH's temple (Gen. 1:26-28; Middleton 2005, 87).

Unlike the other Ancient Near Eastern religions, however, the image of the Israelite deity is not carved from stone or wood; it is not fashioned "with human hands" (a Hebraism that suggests idolatry) (McDonough 2017, 193; Beale 2004, 224 - 226). ${ }^{18}$ Rather, YHWH's image is a living, breathing organism: human being, an image YHWH himself makes. This helps explain the Second Commandment, of course, but there's a further reason I mention YHWH's image and its Ancient Near Eastern context, viz., it helps shed light on what an "image of God" is. For, as it turns out, "image of God" language is not unique to Israelite theology. Moreover, it seems as though the Israelites borrowed the term for at least one particular purpose: to explain what it is that humans do. The

18 Thus Beale: "The word cheiropoietos ('handmade') occurs 14 times in the Greek OT and always refers to idols! Outside Acts 7:48, the word in the NT occurs five times, once with respect to pagan temples (Acts 17:24), three times to the Jerusalem temple that was passing away (Mark 14:58; Heb. 9:11, 24), and once with regard to physical circumcision (Eph. 2:11). The wording 'the work of men's hands' in the Greek OT refers without exception to idols..." (2004, 224 note 45). Beale also notes: "[s]imilarly, 1 Kings 6:7 says that Solomon's temple was 'built of stone prepared at the quarry, and there was neither hammer nor axe nor any iron tool heard in the house while it was being built.' This description of the silence of human tools during the construction of Solomon's temple may be a subtle pointer to the ultimate temple which would be made completely without human hands." $(2004,226)$. Given this, I'm tempted to think that the 1 Kings passage is meant to communicate that Solomon's building project was not idolatrous. Making an argument for that is outside my purview. 
writer of the Genesis 1 account assumes (so goes the argument) that his readers/hearers will know what divine images do. They represent the sovereign rule and power of a deity in a particular geographical location (Middleton 2005, 25). Image bearers have a job. On this way of thinking, "image of God" is the title of a vocation or an office rather than a term that designates a kind of object (that is to say, in metaphysical terms, imago $D e i$ is not a kind sortal. Compare: "office assistant" denotes a vocation, it doesn't tell us what sort of thing fills the role; it could be a computer, a robot, a female human, a male human, or some other sort of thing).

If the designation "image of God" assigns or denotes a particular role, namely, one that proclaims a deity's sovereign presence in a land, then the "image of God" is a matter of function. That the imago Dei is a functional term is common in biblical theological understandings of the human being and his/her role in the cosmos. Often, this is placed in contradistinction to classic views of the image, views that suggest an ontological similarity between a deity and her/his image. For example, Wright confidently declares that the functional reading, "rules out at a stroke centuries of puzzle as to what aspect of humanity might be supposed to be the divine 'image'; that isn't the point. The picture is vocational..." (Wright 2017, 3). Wright's argument, I take it, is that, if the label "image of God" is vocational, then it is not ontological (i.e., it is not a kind sortal). Classically, Christianity affirms that the imago Dei is a kind sortal, for it is thought to explain essential aspects of the species "human being." Some of these supposedly essential components of the human being are a rational and immaterial mind/soul and free will. For, so goes the argument, God is a rational/immaterial mind with free will, and humans are like God (qualifications notwithstanding for the unlimited nature of the Creator and the limited nature of created humans). ${ }^{19}$ The way the biblical theologian portrays the argument, then, seems to put the classic understanding of the imago Dei and a contemporary biblical theological understanding at loggerheads. Are they?

As with the biblical theological portrait outlined in §I, I'm willing to follow the biblical theologian in thinking that the imago Dei is a vocational title. However, I think it's too quick to dismiss the tradition's understanding of the human being. As it turns out, the functional view and the ontological view are consistent and mutually informative. To see why, consider what Richard Middleton says about the imago Dei:

"When the clues within the Genesis text are taken together with comparative studies of the ancient Near East, they lead to what we could call a functional - or even missional-interpretation of the image of God... On this reading, the imago

\footnotetext{
${ }_{19}$ See Jaroslav Pelikan's outline of a Patristic argument along these lines (e.g., in the thought of Gregory of Nyssa) in (Pelikan 1993, 131). There are other offered components too. Some think that the triune nature of God explains why those that are made in his image are essentially communal beings. See, for example, (Grenz 2001).
} 
Dei designates the royal office or calling of human beings as God's representatives and agents in the world, granted authorized power to share in God's rule or administration of the earth's resources and creatures...Since the main function of divinity in both Israel and the ancient Near East is precisely to rule (hence kings were often viewed as quasidivine), it is no wonder that Psalm 8 asserts that in putting all things under their feet and giving the dominion over the works of God's hands, God has made humans "little less than ělōhîm" (8:5-6 [MT 8:6-7]). It does not matter whether élōhîm is translated as "God" or (with the Septuagint) "angels," the meaning is virtually unchanged. In the theology of both Psalm 8 and Genesis 1, humans...have been given royal and thus godlike status in the world" (Middleton 2005, 27 - 28).

According to Middleton, the human being, as image bearer, is meant to share in God's rule and administration over God's creation (cf. also Gorman 2014, 357). Moreover, because God rules his creation in wisdom, humans are meant to help rule in light of that same wisdom (cf. Proverbs 1 - 4; Middleton 2005, 87 - 88; Walton 2015, 144; Beale 2004, 162). God's image bearers, then, are meant to be wise.

This conclusion elicits at least two questions: What sorts of things are wise? What is wisdom? Following Oliver O'Donovan, one can reasonably define wisdom this way: "the intellectual apprehension of the order of things which discloses how each being stands in relation to each other" (O'Donovan 1986, 26). Putting it another way, wisdom is the observing and understanding of an inherent God-designed order in the creation and the conforming of oneself to that order (cf. Prov. 1:7; Job 28:28; Walton 2015, 124, 143). ${ }^{20}$ On this understanding of wisdom, one that is wise can discern teleology within nature and societies, that there's a way that God set up the cosmos to function, and that there's a purpose for the whole and each part of the whole. Things that are wise, then, are things that can observe and understand order. I submit that such things are rational things and I take it that rational things are persons. ${ }^{21}$ If this is correct, and given the sort of task to which the office holder of imago Dei is called, it follows that the sort of thing occupying that office is a person. Moreover, according to the biblical story, the office holder is not $a$ person; it's democratized to all persons of a particular kind, viz. humans (Middleton 2014, 44 - 45; Middleton 2005, 88ff; Beale 2004, 117). Thus, given the particular role assigned to YHWH's image, there's an entailment between being YHWH's image and being a person, a rational human being. ${ }^{22}$

\footnotetext{
${ }^{20}$ Though wisdom is often (perhaps rightly) reflected on in the discipline of philosophy, John Walton, a biblical theologian, offered these helpful sentiments.

${ }^{21}$ Boethius classically defines a person as an individual substance of a rational nature. Cf. (Boethius n.d., III.34). See also (Aquinas 1952, Ia.29.1 respondeo).

${ }^{22}$ To not take us too far afield, let me note here briefly that what I mean by "rational human being" is a species designation, one that tells us about the sort of thing a human is. Another way to say it is: rational animal. All I mean by this is that, by virtue of being a member of the particular species "human being,"
} 
Let me further clarify why it is that I think the vocational/functional and ontological views of the imago Dei are mutually informative. To do so, consider the following two senses of the image of God:

IG $_{\text {ANE: }}$ Any $x$ is an image of a god if $x$ represents the rule and power of a deity in a particular geographical area.

IGor: Any $x$ is an image of YHWH if $x$ represents the rule and power of YHWH in YHWH's creation and, with YHWH, $x$ co-rules YHWH's creation.

I submit that $\mathrm{IG}_{\text {AnE }}$ and IGor are consistent. This is so because what we are told by exegetes is that what it is for YHWH's images to represent the rule and power of YHWH (a deity) is for his images to co-rule with him, to act as his vice-regents in the cosmos.

Why does it matter that these two notions of the imago Dei are consistent? For this reason: conceivably there are myriad ways in which YHWH might have wanted his image bearers to represent his rule and reign in a particular geographical area. For example, he might have, consistent with the gods of ANE religions, wanted his images to be stationary and inanimate images of wood and stone. If that's right, then there's a sense in which N. T. Wright's casual dismissal of the tradition's understanding of the imago Dei is correct. It's not the case that the term "image of God" delivers a metaphysics of human beings. Yet, there's also a sense in which Wright's dismissal is wide of the mark. Indeed, his dismissal makes the same mistake (if it is one) as the one who thinks that the imago Dei just is a term denoting an ontological similarity between humans and YHWH. The mistake is to think that 'image of God' has just one sense. Instead, it seems as though 'image of God' may be something of a generic term, under which there are specific varieties. I think the biblical theologian will grant me this nuance, for the exegetical evidence appears to suggest that YHWH's images are given a very different sort of task than the images of other ANE deities (Walton 2015, 48 - 49). ${ }^{23}$ Thus, while the generic $\mathrm{IG}_{\mathrm{ANE}}$ may point solely to a vocational/functional designation, a species of image, IGor, for example, might deliver a vocational calling that entails a particular ontology of the image bearer. ${ }^{24}$ As I argue above, in the specific sense, the image of

one is rational, even if not actually or actively rational (i.e., all humans are potentially rational). I follow Thomas Aquinas and some of his recent interpreters here. Cf. (Aquinas 1968, VI.6), (Brown 2005, 51 - 52), (Stump 2003, 53), and (Oderberg 2007, 8, 47ff, 93ff).

${ }^{23}$ Other ANE religions suggested that humans were created to serve the gods by providing them (the gods) with food, housing, and clothing. This is what Walton calls "The Great Symbiosis." Contrarily, YHWH needs nothing from humans. Rather, he invites them to participate in stewarding his creation with him. See also, (Middleton 2014, 44)

${ }^{24}$ For another recent treatment of an argument concluding that a functional account entails an ontological account, see (Farris 2017, 33 - 35). Farris argues that the particular functions to which YHWH's 
YHWH does entail a particular ontology of the image bearer, viz., that it's a person and a human. ${ }^{25}$

There is one other vitally important characteristic that contemporary research brings to bear on what it is to be an $\mathrm{IG}_{\text {ANE }}$ (and, thus, an IGor). According to experts in ANE understandings of the image of God, image bearers are physical, visual, and locatable entities; they are embodied. These features are, according to the research, built in to the meaning of the term (Middleton 2005, 25). The upshot is that there are no such things as invisible, immaterial, non-spatially locatable images of God, at least, if one thinks that the ANE is whence the meaning of the term is derived. Given that it is, the following principle is true:

Embodied Images (EI): for all entities $y$, if $y$ is an image of God, then $y$ is embodied.

A moment's reflection on (EI) delivers some potentially interesting implications. For, if one thinks that all human persons are essentially image bearers, and that every human person is essentially a human person, then it follows that no human person can be disembodied. Mounting a defense of such an argument, though, takes me too far afield. ${ }^{26}$ Instead, I want now to turn my attention, with IG $_{\text {ANE, }}$ IGor, and (EI) in hand, to an analytic exploration of the bodily resurrection and the telos of all things. That is, I wish to show how combining the resources of analytic theology with the deliverances of

images are called, coupled with some additional philosophical considerations, reveals the essentially immaterial nature of the human being. We disagree on this score, viz., that humans are essentially immaterial; nevertheless, his arguments make similar moves to those I provide above. See also (Moreland $2009,4-5)$. See note 26.

${ }^{25}$ One might think this is an odd way of phrasing things. I phrase it this way because I take it that this allows for a consistent position with the biblical data about YHWH's image in the Garden in Eden and also an orthodox Christology, which suggests that Jesus Christ both is the true image of God and not a human person, but a divine person with a human nature. He is, then, a person and human, but not a human person.

${ }^{26}$ (EI) is a central reason I disagree with the conclusions of the function to ontology arguments Farris and Moreland (independently) make concerning the imago Dei. I agree, given the particular representative role that YHWH wants of his images, that this particular function implies some ontological things about YHWH's images (see note 24). I disagree on in what the ontology consists. The difference between Farris's view, Moreland's view, and my own view is that theirs doesn't take into account the essentially physical, locatable, and visible nature of image bearing. For space, I leave aside discussion of theories of the divine image offered by, for example, Oliver Crisp in his (2016, 51 - 70) and Jason McMartin in his (2013). Crisp suggests that the divine image is, at least in part, seated in the ability of individual concrete human natures possibly to have been united hypostatically to the Logos. McMartin's thesis is that the imago Dei consists in the capax Dei, the ability for relationship/participation with/in God (McMartin 2013, 136 - 150). I take it that McMartin's thesis is consistent with the sketch I advance here; but he draws out his picture of the image without reference to temple theology and holistic eschatology such that our individual points of emphasis are different. And, though it may be the case that the view I advance here implies his view, it's not clear that his view implies mine. 
JAMES T. TURNER, JR.

holistic eschatology and temple theology can clarify why it is that human beings will be bodily resurrected into the New Creation.

\section{The Temple, Holistic Eschatology, and Bodily Resurrection}

Given sections I-III, call the actual world "W," assume that it's shorthand for "the actual and entire created order," and consider the following argument:

1. W's telos is to be YHWH's temple, the place in which YHWH dwells with and is worshipped by his creation.

2. W's telos will be completed at the eschaton. ${ }^{27}$

3. At the eschaton, $W$ will be YHWH's temple, the place in which YHWH dwells with and is worshipped by his creation. (From 1,2)

4. An essential property of $W$ is that it contains $Y H W H ' s$ image bearers.

5. The conjunction $<\mathrm{IG}$ or is true and it's true that human beings are $\mathrm{IG}_{\mathrm{or}}>$ is true.

6. EI is true

7. Therefore, at the eschaton, $W$ will contain embodied human beings. (From $3-6$ )

I submit that, given sections I and III, this argument seems straightforward, almost obvious. Nevertheless, (4), at least, deserves further comment. Doing so also will help clarify just how interweaving holistic eschatology and temple theology makes a case for why there will be a human bodily resurrection.

Look again at (4). It states that an essential property of $W$ is that it contains YHWH's image bearers. Notice that (4) concerns only the actual created order (or, in possible worlds semantics, the actual world). (4) is silent about what other sorts of cosmoi YHWH might have created (i.e., other possible worlds); (4) concerns only $W$, the actual world/creation. I haven't the space fully to develop arguments for (4); so, for purposes of my argument, I'm going to stipulate that (4) is true-at least, that it's true given sections I and III. The biblical theologians espousing that which I've overviewed suggest that, in the case of this creation, YHWH's plan always included his image bearers, viz., human beings, to be his vice-regents. His temple will include his image and his image bearers will co-rule with him (Walton 2015, 56 - 57, 159; McDonough 2017, 160).

(7), then, follows directly from premises (4) - (6) (premises (5) and (6) are those that explicate more clearly the otherwise suppressed understanding of YHWH's image in (4)). However, (7), as stated, doesn't yield the result toward which I'm aiming with the argument. Recall that I want to clarify how interweaving holistic eschatology and temple theology makes a case for why there will be human bodily resurrection. Unfortunately, (7) is silent about resurrection. What it says is that at the eschaton, $W$ will

\footnotetext{
${ }_{27}$ I'm tempted to say "consummated" rather than "completed."
} 
contain embodied human beings. It does not say how they get there. What I need is a more specific conclusion like the following:

9. Therefore, at the eschaton, $W$ will contain resurrected human beings.

To get to (9), though, I need a further premise.

What sort of premise might get from (7) to (9)? In answer, allow me to offer the following:

8. The eschatological bodily resurrection furnishes $W$, at the eschaton, with embodied human beings.

From (7) and (8), (9) follows immediately. Here's a clearer look:

7. At the eschaton, $W$ will contain embodied human beings.

8. The eschatological bodily resurrection furnishes $W$, at the eschaton, with embodied human beings.

9. Therefore, at the eschaton, $W$ will contain resurrected human beings. (From 7,8 )

By my lights, (8) should carry the endorsement of biblical theologians thinking through temple theology and holistic eschatology. Additionally, there seem to be a number of biblical texts that suggest what I take to be the semantic content of (9) (e.g., 1 Cor. 15:1257; Rom. 8:18-25), viz., that the promise of the New Creation (i.e., the eschatological $W$ ) includes the bodily raising of the dead saints into the New Creation. ${ }^{28}$ Thus, (7) - (9) paint a clear picture for why humans will be bodily resurrected into the New Creation: it is a way $W$ is furnished with image bearers. ${ }^{29}$

An important upshot of the argument from (1) - (9) is that, given what "temple theology" suggests is the point and purpose of God's creation, human afterlife contributes to the telos of the whole of God's creation, God's eschatological cosmic temple. That is, human afterlife is not the central focus of YHWH's eschatological purposes; but it is an essential component of God's eschatological purposes. Thus, beyond helping explain why (1) - (9) are conceptually connected, a reason that holistic eschatology is important to the doctrine of resurrection (and Christian doctrines of afterlife in general) is that it provides a framework for placing an importance on the redemption of the whole and the redemption of human beings. Temple theology, then,

\footnotetext{
${ }^{28}$ I provided further arguments elsewhere (Turner 2015; Turner 2017; Mugg and Turner 2017).

${ }^{29}$ Notice, too, that (8) allows space for theologians to consider whether, alongside bodily-resurrected humans, God might create entirely new human beings in the New Creation or even the continuation of pro-creative activities. Though, I do not endorse these positions.
} 
fills in more fully why it should be that YHWH renews the whole of his creation and human beings as essential parts of that whole. But, of course, humans (given their image bearing nature) cannot be renewed and redeemed fully without being bodily resurrected (see EI). Consequently, if YHWH intends to redeem and renew human beings fully, then $\mathrm{YHWH}$ will bodily resurrect human beings into the New Creation.

\section{Conclusion}

If the rise in biblical theological support for "temple theology" indicates that the systematic theologian should take its deliverances seriously, then analytic theologians, as systematic theologians, should take seriously N. T. Wright's clarion call: temple theology should be front and center in one's theological study and construction. Add to this the biblical theological insights concerning holistic eschatology and it becomes apparent that Christian dogma concerning personal eschatology-not to mention eschatology and theology, generally-must include robust accounts of bodily resurrection. After all, bodily resurrection is, as I say above, part and parcel of the Temple-patterned telos of God's creation. Because of this, I've used this paper as a prolegomenon (of sorts) for analytic engagement with biblical theology. The hope is that the analytic theologian should be able to see that the biblical theologian is worthy of attention-particularly with respect to holistic eschatology and temple theology-and that, through analytic analysis, important matters of Christian dogma (e.g., the bodily resurrection and imago Dei) can be clarified..$^{30}$

\section{Bibliography}

Aquinas, St. Thomas. 1952. The Summa Theologica. Vol. 1, in Great Books of the Western World, no. 19. Edited by Robert Maynard Hutchins. Translated by Fathers of the English Dominican Province. Chicago, IL: Encyclopedia Britannica.

Aquinas, St. Thomas. 1968. On Being and Essence. $2^{\text {nd }}$ Revised edition. Translated by Armand Maurer. Toronto: Pontifical Institute of Mediaeval Studies.

Bauckham, Richard. 2007. “Eschatology." In The Oxford Handbook of Systematic Theology, eds. John Webster, Kathryn Tanner, and Iain Torrance, 306 - 322. Oxford, UK: Oxford University Press.

Barker, Margaret. 2012. "Wisdom and the Other Tree: A Temple Theology Reading of the Genesis Eden Story." Paper presented at the Society of Biblical Literature, Amsterdam, NED.

\footnotetext{
${ }^{30}$ Research for this paper was completed as part of the Analytic Theology Project at Fuller Theological Seminary, a project funded by a grant from the John Templeton Foundation. Thanks to Roger Turner, Joshua Farris, and two anonymous reviewers for feedback on a previous draft of this essay.
} 
Beale, G. K. 2004. The Temple and the Church's Mission: A Biblical Theology of the Dwelling Place of God. Downers Grove, IL: InterVarsity Press.

Beale, G. K. and Mitchell Kim. 2014. God Dwells Among Us. Downers Grove, IL. InverVarsity Press.

Boethius. (n.d.). "A Treatise Against Eutyches and Nestorius." In The Theological Tractates. Translated by H. F. Stewart and E. K. Rand, 30 - 46. Grand Rapids, MI: Christian Classics Ethereal Library. http://www.ccel.org/ccel/boethius/tracts.pdf

Brown, Christopher. 2005. Aquinas and the Ship of Theseus. London, UK: Continuum.

Crisp, Oliver D. 2007. Divinity and Humanity: The Incarnation Reconsidered. Cambridge: Cambridge University Press.

Crisp, Oliver D. 2009. God Incarnate: Explorations in Christology. London: T\&T Clark.

Crisp, Oliver D. 2016. The Word Enfleshed. Grand Rapids, MI: Baker Academic.

Descartes, René. 1986. Meditations on First Philosophy with Selections from the Objections and Replies, edited and translated by John Cottingham. Cambridge, UK: Cambridge University Press.

Enns, Peter. 2012. The Evolution of Adam: What the Bible Does and Doesn't Say About Human Origins. Grand Rapids, MI: Brazos Press.

Farris, Joshua R. 2017. The Soul of Theological Anthropology: A Cartesian Exploration. London, UK: Routledge.

Fergusson, David. 1985. "Interpreting the Resurrection." Scottish Journal of Theology 38, no. 3: $287-305$.

Fergusson, David. 2000. "Introduction." In The Future as God's Gift: Explorations in Christian Eschatology, edited by David Fergusson and Marcel Sarot, 1 - 7. Edinburgh, UK: T\&T Clark.

Fretheim, Terence E. 2014. "The Reclamation of Creation: Redemption and Law in Exodus." In Cult and Cosmos: Titling Toward a Temple-Centered Theology, edited by L. Michael Morales, 317 - 330. Leuven, BE: Peeters.

Gorman, Jr., Frank H. "Priestly Rituals of Founding: Time, Space, and Status." In Cult and Cosmos: Titling Toward a Temple-Centered Theology, edited by L. Michael Morales, 351 - 366. Leuven, BE: Peeters.

Grenz, Stanley J. 2001. The Social God and the Relational Self. Louisville, KY: Westminster. Harris, Murray J. 1983. Raised Immortal. London, UK: Marshall, Morgan, and Scott. Hasker, William. 2013. Metaphysics and the Tri-Personal God. Oxford, UK: Oxford University Press.

Levenson, Jon D. 1984. “The Temple and the World." The Journal of Religion 64, no. 3: 275 $-298$.

Levenson, Jon D. 2014. "Cosmos and Microcosm." In Cult and Cosmos: Titling Toward a Temple-Centered Theology, edited by L. Michael Morales, 227 - 248. Leuven, BE: Peeters. 
JAMES T. TURNER, JR.

Lundquist, John M. 2014. "The Common Ideology of the Ancient Near East." In Cult and Cosmos: Titling Toward a Temple-Centered Theology, edited by L. Michael Morales, 49 68. Leuven, BE: Peeters.

McCall, Thomas H. 2015. An Invitation to Analytic Christian Theology. Downers Grove, IL: IVP Academic.

McDonough, Sean M. 2017. Creation and New Creation: Understanding God's Creation Project. Peabody, MA: Hendrickson.

McMartin, Jason. 2013. "The Theandric Union as Imago Dei and Capax Dei." In Christology: Ancient and Modern, edited by Oliver D. Crisp and Fred Sanders, 136 150. Grand Rapids, MI: Zondervan.

Middleton, J. Richard. 2005. The Liberating Image. Grand Rapids, MI: Brazos.

Middleton, J. Richard. 2014. A New Heaven and a New Earth: Reclaiming Biblical Eschatology. Grand Rapids, MI: Baker Academic.

Moreland, J. P. 2009. The Recalcitrant Imago Dei: Human Persons and the Failure of Naturalism. London, UK: SCM.

Mugg, Joshua and James T. Turner, Jr. 2017. "Why a Bodily Resurrection? The Bodily Resurrection and the Mind-Body Relation." Journal of Analytic Theology 5: 121 - 144.

Mullins, R. T. 2016. “The Difficulty with Demarcating Panentheism." Sophia 55: 325 346.

Oderberg, David S. 2007. Real Essentialism. London, UK: Routledge.

O'Donovan, Oliver. 1986. Resurrection and Moral Order. Grand Rapids, MI: Eerdmans.

Osborn, Ronald E. 2014. Death Before the Fall. Downers Grove, IL: IVP Academic.

Pawl, Timothy. 2016. In Defense of Conciliar Christology: A Philosophical Essay. Oxford, UK: Oxford University Press.

Pelikan, Jaroslav. 1993. Christianity and Classical Culture. New Haven, CT: Yale University Press.

Polkinghorne, John. 2002. "Eschatological Credibility: Emergent and Teleological Processes." In Resurrection: Theological and Scientific Assessments, edited by Ted Peters, Robert John Russell, and Michael Welker, 43 - 55. Grand Rapids, MI: Eerdmans.

Rea, Michael C. 2009. "Introduction." In Analytic Theology: New Essays in the Philosophy of Theology, edited by Oliver D. Crisp and Michael C. Rea, 1 - 30. Oxford, UK: Oxford University Press.

Rowland, Christopher. 2008. "The Eschatology of the New Testament Church." In The Oxford Handbook of Eschatology, edited by Jerry L. Walls, 56 - 72. Oxford, UK: Oxford University Press.

Stump, Eleonore. 2003. Aquinas. London, UK: Routledge.

Turner, Jr. James T. 2015. "On the Horns of a Dilemma: Bodily Resurrection or Disembodied Paradise?" International Journal of Philosophy and Theology 75 no. 5: 406 421. 
Turner, Jr. James T. 2017. "Purgatory Puzzles: Moral Perfection and the Parousia." Journal of Analytic Theology 5: 197 - 219.

Walton, John H. 2015. The Lost World of Adam and Eve. Downers Grove, IL: IVP Academic.

Walton, John H. 2009. The Lost World of Genesis One: Ancient Cosmology and the Origins Debate. Downers Grove, IL: IVP Academic.

Weinfeld, Moshe. 2014. "Sabbath, Temple, and the Enthronement of the Lord: The Problem of the Sitz im Leben of Genesis 1:1-2:3." In Cult and Cosmos: Titling Toward a Temple-Centered Theology, edited by L. Michael Morales, 149 - 160. Leuven, BE: Peeters.

Wright, Christopher J. H. 2004. Old Testament Ethics for the People of God. Downers Grove, IL: InterVarstiy Press.

Wright, N. T. 2015. "Excursus." In The Lost World of Adam and Eve by John H. Walton, 170 - 180. Downers Grove, IL: IVP Academic.

Wright, N. T. 2017. "History, Eschatology and New Creation: Early Christian Perspective on God's Action in Jesus." Paper given at the 2017 Logos Conference in St. Andrews, UK. 